J. Clin. Chem. Clin. Biochem.

Vol. 20, 1982, pp. $95-102$

\title{
Effect of Transient Hypoxia in Skeletal Muscle on Enzyme Activities in Lymph and Plasma
}

\author{
By J. Lindena, W. Küpper and I. Trautschold \\ Department of Clinical Biochemistry and Department of Laboratory Animal Science, \\ Medical School, Hannover, FRG
}

(Received July 7/October 21, 1981)

Summary: The effect of hypoxia lasting one hour on the hind leg muscle of anaesthetised dogs was investigated. Ten enzyme activities in plasma and leg lymph, and the lymphatic transport of these enzymes were investigated. Enzymes with high activity in muscle, like creatine kinase, lactate dehydrogenase, malate dehydrogenase and adenylate kinase only show an increase in the plasma, if lymph - propulsed by passive motion of the hind leg - can reach the intravascular space. This effect is independent of transient hypoxia. Depending on the level of enzyme activity in the muscle, the activity in leg lymph is up to 6-fold higher than in plasma. Enzymes from muscle have to be transported into the blood by lymph flow and not via a direct interstitial-venous entry. The results are discussed especially with respect to enzyme activity changes in plasma during physical exercise.

\section{Einfluß einer kurzfristigen Hypoxie des Skelettmuskels auf Enzymaktivitäten in Lymphe und Plasma}

Zusammenfassung: An anästhesierten Hunden wurde der Einfluß einer einstündigen Hypoxie der Hinterbeinmuskulatur auf die Höhe der Aktivitäten von 10 Enzymen im Plasma, der Beinlymphe und auf die Transportrate der Lymphe für diese Enzyme untersucht. Enzyme mit hoher Aktivität im Muskel wie Kreatinkinase, Lactatdehydrogenase, Malatdehydrogenase und Adenylatkinase steigen im Plasma nur dann an, wenn Lymphe - durch passive Bewegung der Gliedmaße getrieben - den Intravasalraum erreicht. Dieser Effekt ist unabhängig von vorausgegangener Hypoxie. Abgestuft nach der Höhe der Enzymaktivität im Skelettmuskel findet sich in der Beiklymphe eine bis zu 6fach höhere Aktivität gegenüber dem Plasma. Aus dem Skelettmuskel gelangen Enzyme überwiegend lymphatisch in den Intravasalraum und nicht durch interstitiell-venösen Übertritt. Die Ergebnisse werden besonders unter dem Gesichtspunkt von Änderungen der Enzymaktivitätẹn im Plasma bei körperlicher Belastung diskutiert.

\section{Introduction}

The most commonly used explanation for changes of enzyme activities in plasma during and after physical exertion is an enzyme release from cells, due to a relative transient hypoxia, which is believed to lead to an increased permeability of the cellular membrane for macromolecules caused by a depletion of cellular energy $(1,2)$. Thereby enzyme release from muscle cells should contribute to the main part of elevated enzyme activities in plasma (2), whereas other authors attribute more importance to the liver $(3,4)$. Further factors which can contribute to changes of enzyme activities in plasma are haemoconcentration (5), intravascular haemolysis $(6,7)$, and the type, intensity (8) duration (2) and extent (9) of the work executed. All these studies performed in humans, however, are phenomenological interpretations from enzyme activities in plasma. The intervening interstitial space, however, has been given less emphasis. There are, however, some experimental results and considerations, which attribute an exceptional role to the interstitial/lymphatic compartment in understanding the pathophysiological mechanism of enzyme activity changes in plasma during and after exertion.

1. The interstitial/lymphatic fluid compartment is about 4 times larger than the intravascular space.

2. Even under physiological conditions enzyme activities in the ductus thoracicus, and leg lymph are several fold higher compared to plasma (10-13).

3. During physical exertion inflow of interstitial fluid via ductus thoracicus into the blood rises several fold $(14,15)$.

4. There are indications that due to the extremely low capillary permeability in skeletal muscle $(16,17)$ macromolecules are transported predominantly via the lymphatics $(18-20)$.

Hitherto, however, lymph seems to be a forgotten organ and only a few groups have paid attention to the effect of physical activity on enzyme activities in this extracellular fluid compartment $(10,21-27)$. 
The effect of transient hypoxia of skeletal muscle on enzyme activities in leg-lymph and plasma and whether these enzymos reach the intravascular compartment preferably via lymph or by direct interstitial-venous entry, are, however, controversial questions.

\section{Material and Methods}

\section{Experimental procedure and sampling}

Mongrel dogs of cither sex, weighing between 23 and $34 \mathrm{~kg}$ were used. Anaesthesia was induced by intravenous injection of sodium pentobarbital ( $30 \mathrm{mg} / \mathrm{kg}$ body weight) after intravenous premedication with phenotiazine (Combelen) and methadone hydrochloride (Polamivet). Additional doses were given as needed under reflex control. After endotracheal intubation spontaneous respiration continued. The left external jugular vein was cannulated for obtaining central venous blood samples and for addition of drugs. Local venous limb blood was obtained by cannulating the $\mathbf{V}$. iliaca interna. Laparotomy was performed in the Linea alba. The left truncus lumbalis joins the aorta dorsomedialy after forming a unique vessel from several sources of the $\mathrm{Ln}$. iliaci mediales (28). Cannulation was performed by a Silastic tube (Dow Corning Corporation) with an inner and outer diameter of 0.76 and $1.65 \mathrm{~mm}$ respectively. Lymph was collected in preweighed test tubes under addition of heparin at intervals of $15 \mathrm{~min}$ and the volume was determined gravimetrically. A corresponding blood sample from the jugular yein and the V. iliaca interna (only in the experimental groups $1,2,3,5$, where surgical procedures were performed) was drawn at the end of each lymph sampling. Both heparinised blood and lymph were centrifuged for $2 \mathrm{~min}$ at $15000 \mathrm{~g}$ and the supernatants were stored at $-70^{\circ} \mathrm{C}$. Lymph flow, which slows down nearly to zero in the immobile leg, was induced by flexing and extending the limb manually with a frequency of $60 / \mathrm{min}$.

The experimental procedure was strongly time controlled for all groups independent of the different time consuming preparations for the particular group before starting the actual experiment.

Skeletal muscle samples were obtained from the M. gastrocnemius and M. sartorius. Samples were plunged into ice-cold $0.15 \mathrm{~mol} / 1$ sodium chloride, freed from connective tissue, and weighed. Until assayed they were stored at $-70^{\circ} \mathrm{C}$. Homogenisation was carried out in ice-cold Krebs-Ringer buffer containing $10 \mathrm{ml} / 1$ ethylphenylpolyethyleneglycol, NP 40 (FLUKA AG), three times for $30 \mathrm{~s}$ with an interval of $30 \mathrm{~s}$ with an Ultra-Turrax (Janke + Kunkel). Suitable dilutions were prepared from the $15000 \mathrm{~g}$ supernatant in Krebs-Ringer buffer.

Animal groups

The dogs were divided into 2 experimental (1-2) and 4 control (3-6) groups.

\section{Group $1(\mathrm{n}=10)$}

After an initial $15 \mathrm{~min}$ period of lymph collection from the passively moved hind limb, the A. iliaca interna in the limb with the lymphatic cannula was clamped for $60 \mathrm{~min}$ and limb movement was ceased. Blood sampling procedure was continued at $30 \mathrm{~min}$ intervals. After restoration of blood flow, lymph and blood specimens were sampled for a further $180 \mathrm{~min}$ at $15 \mathrm{~min}$ intervals whilst lymph flow was maintained by passive motion of the particular limb.

\section{Group $2(\mathrm{n}=7)$}

Blood and lymph sampling procedure were identical to group 1 , but no hypoxia was applied whilst leg movement was stopped during this period. After this one hour of "rest", blood and lymph sampling continued with passive motion of the leg. In the following groups, which served as controls, no lymph was withdrawn from truncus lumbalis, but influences like anaesthesia, surgery and passive motion were investigated.
Except for a first $15 \mathrm{~min}$ blood sample corresponding to group 1 and 2 , only $30 \mathrm{~min}$ blood samples were obtained further on.

Group $3(n=5)$

This group is identical to group 2, except for lymph collection. After the initial 15 min of passive motion the particular leg "rested" for $60 \mathrm{~min}$, followed by another $180 \mathrm{~min}$ of passive motion in these sham operated dogs.

Group $4(n=5)$ $\therefore$,

This group was only subject to passive motion in the usual manner without any sham operation. That means $15 \mathrm{~min}$ of passive motion were followed by $60 \mathrm{~min}$ of "rest" and another 180 min passive motion.

Group $S(\mathrm{n}=5)$.

Only sham operation without passive motion of one leg was performed. In two of these animals the standard time course of the experiment was followed on overr a total of 13 hours. The results of this subgroup are not shown in the figure, but described under results.

Group $6(\mathrm{n}=2)$

In this group the influence of 60 min of isolated hypoxia without any passive motion was monitored over a total of 13 hours. The results of this group are also not shown in the figure, buit described under results.

\section{Enzyme determination}

The activities of the following enzymes were determined in plasma, lymph and skeletal muscle:

lactate dehydrogenase (EC 1.1.1.27); malate dehydrogenase (EC 1.1.1.37); aspartate aminotransferase (EC 2.6.1.1); alanine aminotransferase (EC 2.6.1.2); crèatine kinase (EC 2.7.3.2); adenylate kinase (EC 2.7.4.3); choline esterase (EC 3.1.1.8); alkaline phosphatase (EC 3.1.3.1); leưcine arylamidase (EC 3.4.11.1); aldolase (EC 4.1.2.13).

Enzyme assays were carried out using ultraviolet= or colorimetric tests on a micrioliter scale at $25^{\circ} \mathrm{C}$. Aldolase was measured at $37^{\circ} \mathrm{C}$ and corrected for $25^{\circ} \mathrm{C}$ with a factor 0.41 , Lactate dehydrogenase, aspärtate aminotransferase, alanine aminotransferase, creatine kinase, alkaline phosphatase and leucine arylamidase were determined with optimised tests according to the Recommendations of the German Society of Clinical Chemistry (29). For creatine kinase determinations the revised standard method with addition of EDTA was used (30). For malate dehydrogenase, aldolase and chöline esterase (substrate: butyrylthiocholine iodide) commercial test kits (Boehringer Mannheim, respectively Merck Darmstadt) iwere used. The assay conditions for adenylate kinase were: triethanolamine buffer $\mathrm{pH} 7.6,70 \mathrm{mmol} / \mathrm{l} ; \mathrm{Mg} 0.7 \mathrm{mmol} / \mathrm{l} ; \mathrm{K} 120 \mathrm{mmol} / \mathrm{l} ; \mathrm{NADH}$ $0.54 \mathrm{mmol} / 1$; phosphoenolpyiruvate $0.4 \mathrm{mmol} / 1$; AMP

$1.3 \mathrm{mmol} / \mathrm{l}$; ATP $1.1 \mathrm{mmol} / 1$; lactate dehydrogenase $22 \mathrm{kU} / \mathrm{l}$; pyruvate kinase $8 \mathrm{kU} / 1$.

All measurements were performed in duplicate. Internal quality control was assured by pooled plasma samples, which had been stored at $-70^{\circ} \mathrm{C}$. Each three specimens were accompanied by a pool sample. Thereby the long-term precision (31) expressed as coefficient of variation (\%) was as follows:

lactate dehydrogenase 5.9, malate dehydrogenase 5.7, aspartate aminotransferase 6.2 , alanine aminotransferase 7.3 , creatine kinase 5.0, adenylate kinase 7.0, alkaline phosphatase 6.3 , leucine arylamidase 7.4 , aldolase 6.0 , choline esterase 7.0 .

Enzyme activities in plasma are given in $U / 1$ and for skeletal muscle in $\mathrm{U} / \mathrm{g}$ wet weight. Lymphatic transport of enzymes is expressed as mU/15 min.

\section{Statistics}

Statistical analyses were done by Student's t-test for sisgnificant mean differences between experimental groups and by the twotailed Student's t-test on individual paired differences within the group (32). 

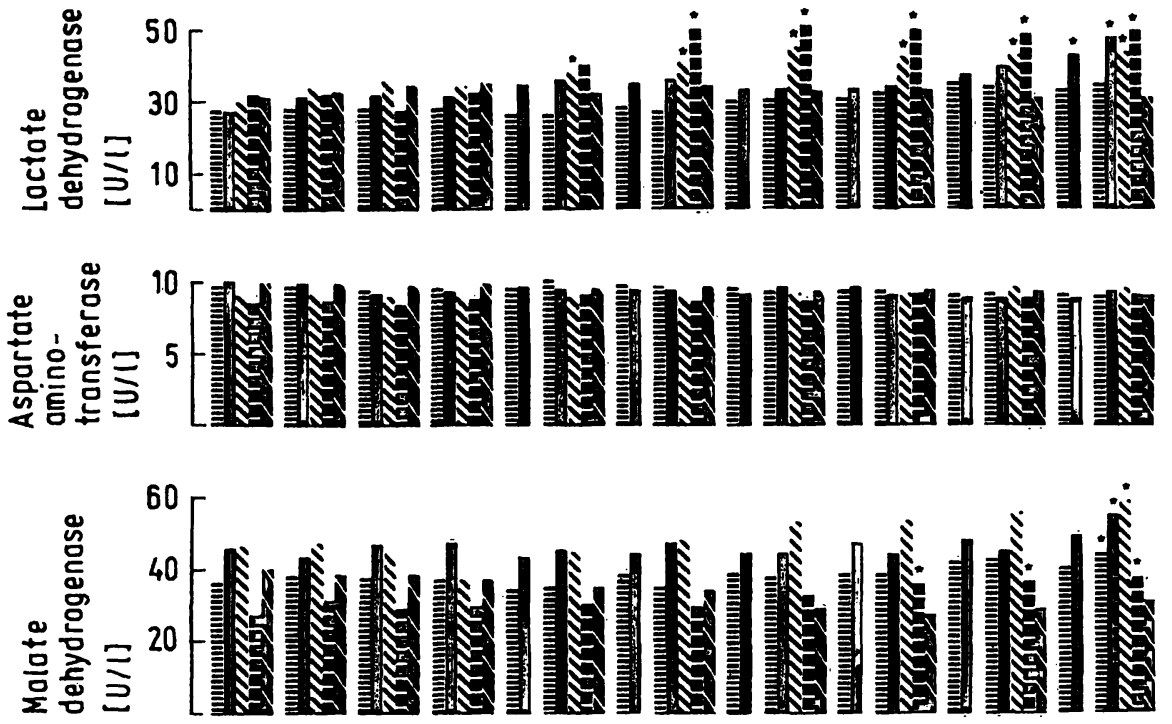

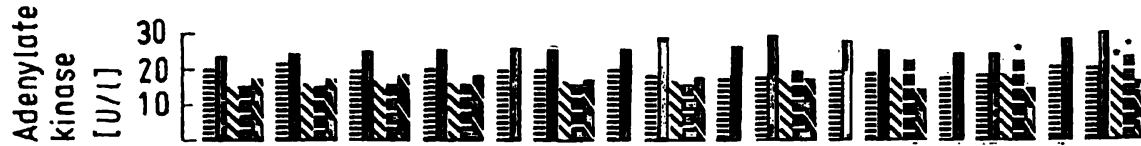

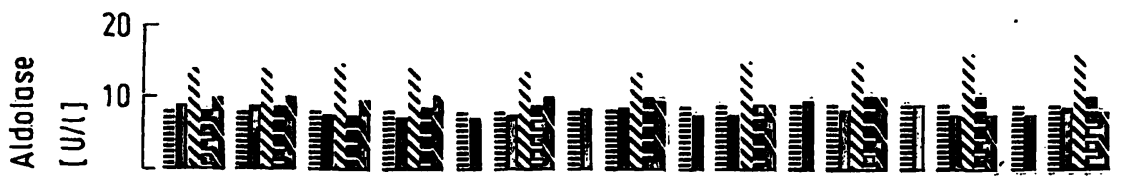

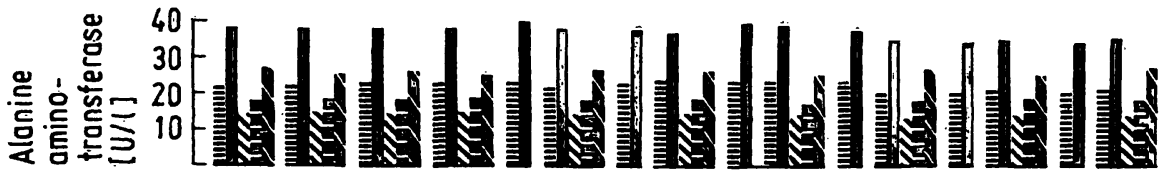

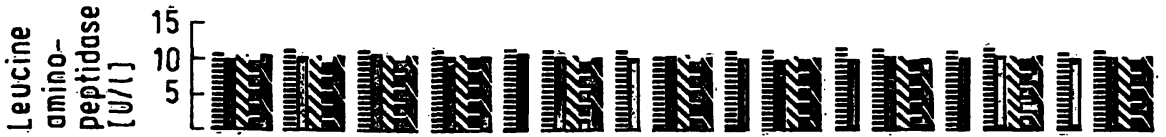

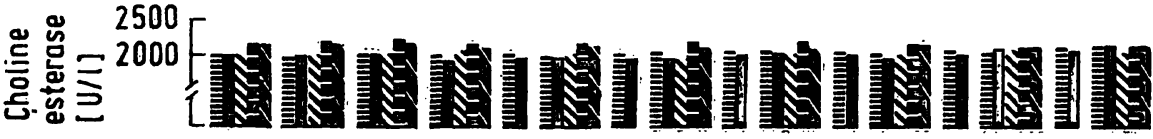

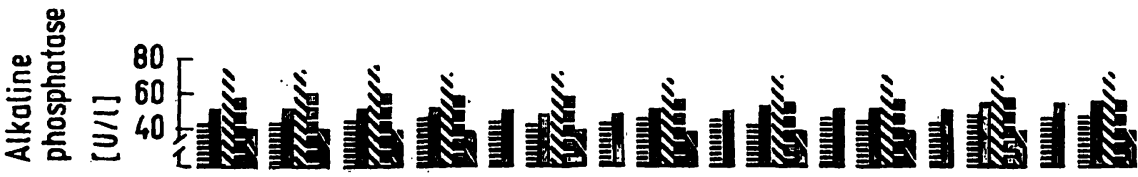

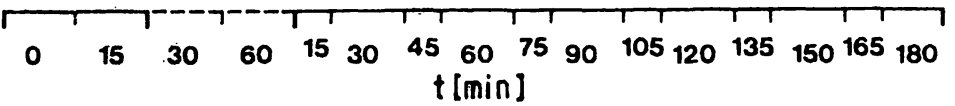
in 

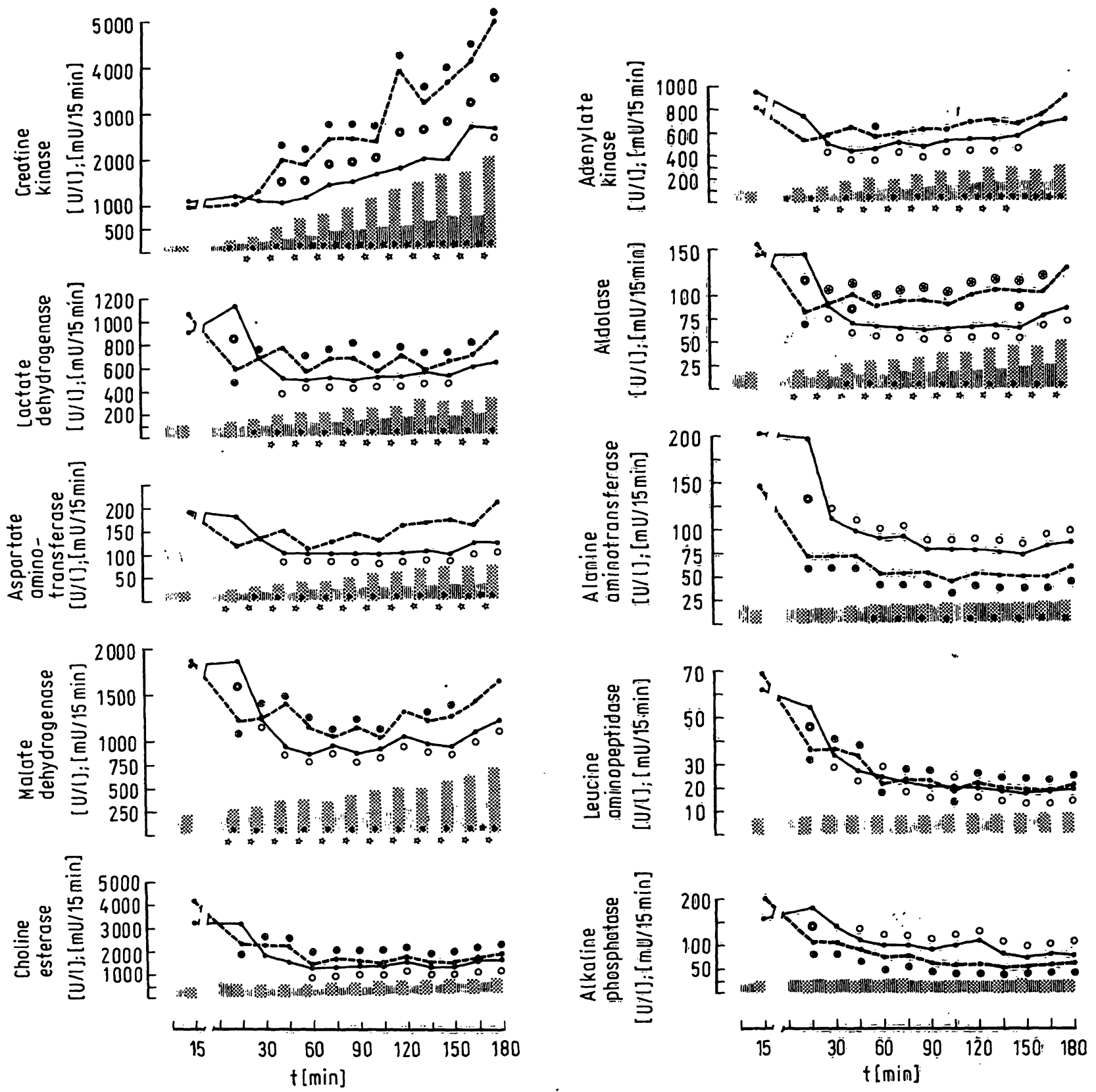

Fig. 2. Changes in enzyme activities in lymph $(\mathrm{U} / 1)$ and lymphatic transport of enzymes (mU/15 min) in the experimental groups 1 and 2 .

Group 1: $15 \mathrm{~min}$ lymph collection, $60 \mathrm{~min}$ hypoxia, $180 \mathrm{~min}$ lymph collection.

愳 lymph enzyme activity, - - - - lymphatic enzyme transport.

Group 2: 15 min lymph collection, 60 min "rest", 180 min lymph collection.

lymph enzyme activity, lymphatic enzyme transport.

Lymph was collected at $15 \mathrm{~min}$ intervals. Lymph propulsion was maintained by passive motion of the particular leg. From the immobile leg during hypoxia and "rest" no lymph flow occurred. Statistical analyses were done by Student's t-test for sigñificant mean differences between both experimental groups and by the two tailed Student's t-test on individual paired differences within the groups in comparison with the first 15 min lymph sample.

Group 1 (within the group): Lymphatic enzyme transport - Lymph enzyme activity.

Group 2 (within the group): 0 Lymphatic enzyme transport $\star$ Lymph enzyme activity.

Between group 1 and 2: $\quad$ Lymphatic enzyme transport, \& Lymph enzyme activity. 


\section{Results}

\section{Plasma enzy me activities}

The results of group 1 to 5 are summarised in figure 1 . Since there were no significant differences between central venous blood and local venous hind limb blood from the $V$. iliaca interna we present only the results obtained from the jugular vein.

Significant changes of the various enzymes are restricted to creatine kinase, lactate dehydrogenase, malate dehydrogenase and adenylate kinase with a different onset during the time course.

If at all, these changes are restricted to group 1 to 4 , which had been subject to passive motion.

The time course of enzyme activity of each two animals in the experimental groups 5 and 6 respectively, in which enzyme activity was followed for 14 hours, showed a similar pattern. Enzyme activity in both groups independent of hypoxia, remained unchanged until 7 hours after starting the experiments. Afterwards a slight increase for creatine kinase, lactate dehydrogenase, malate dehydrogenase, adenylate kinase and alkaline phosphatase was seen, which after 11 hours became steeper. After $13 \mathrm{~h}$ the following rounded off values were measured for group 5 (group 6 in parantheses): creatine kinase 600 (500); lactate dehydrogenase 70 (60); malate dehydrogenase 180 (80); adenylate kinase 30 (40), and alkaline phosphatase 120 (120) U/l.

\section{Lymph enzyme activity}

The results of the experimental groups 1 and 2, which had been subject to lymph collection, are summarised in figure 2 .

Except for leucine arylamidase, choline esterase and alkaline phosphatase, enzyme activity in lymph increases significantly.

\section{Lymphatic enzyme transport}

Lymphatic enzyme transport for the particular enzymes tending in the same direction, independent of hypoxia. For creatine kinase a uniform increase is seen, whereas the transport rate for all other enzymes decreases. In the hypoxic group an early steep decrease is followed by only slight variations and a tendency to rise again at the end of the observation period for lactate dehydrogenase, aspartate aminotransferase and malate dehydrogenase. In group 2 the first 15 min period after "rest" for most enzymes reveals a significantly highẻ transport. Though only significant at very few steps, enzyme transport proceeds at a higher level in the hypoxic group, with the exception of alanine aminotransferase, leucine arylamidase, choline esterase, and alkaline phosphatase.

\section{Lymph flow}

Generally lymph flow decreased. In the hypoxic group a biphasic slope with a steep decline from the initial

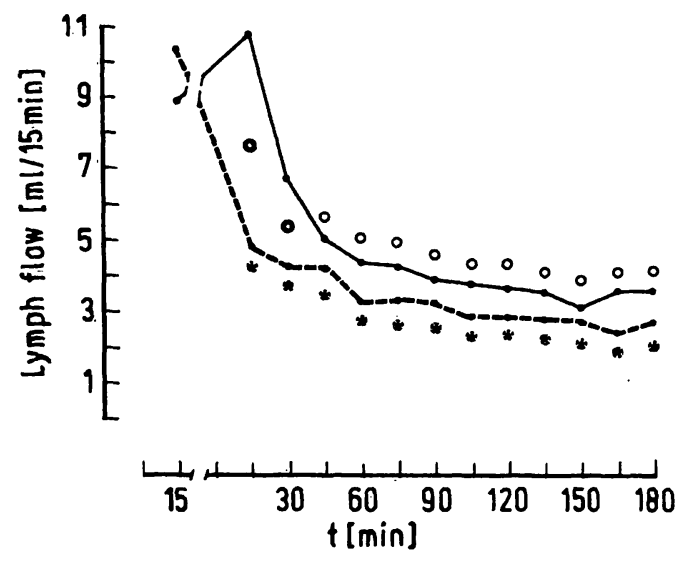

Fig. 3. Changes in lymph flow $(\mathrm{ml} / 15 \mathrm{~min})$ in the experimental group 1 - - and group $2-$. For explanation of groups and probabilities of significance see legend fig. 2 .

15 min sample to the following sample after restoration of blood supply is seen. Thereafter, only a moderate further decrease occurred. In group 2 , however, the very same sample period reveals a new peak after "rest", from which a nearly identical slope of the lymph flow decline happened as compared to the hypoxic group. Generally, lymph flow rate is lower in the hypoxic group.

\section{Lymph-plasma enzyme activity ratio}

For each enzyme the activity of the initial sample with the corresponding activity in plasma, from which lymphplasma quotients are calculated, are listed in table 1. For the majority of the enzymes the activity in lymph is higher compared to plasma. Quotients less than 1 are observed for alkaline phosphatase, alanine aminutransferase, leucine arylamidase and choline esterase. Comparison of the lymph-plasma quotients with the quotient for choline esterase of 0.21 revealed statistical differences for all enzymes with $2 \mathrm{p}$ at least $<0.001$ (see Discussion).

\section{Muscle tissue enzyme activity}

The enzyme activities of the $M$. sartorius and M. gastrocnemius as examples of muscle tissue of the fast and slow type are compared in table 2 . The sartorius muscle contains higher activities of creatine kinase, malate dehydrogenase, and lower activities of lactate dehydrogenase and aldolase, whereas the other enzymes have similar activities.

\section{Discussion}

Recent research in dogs on the changes in serum enzyme activities during or following various types of muscle stimulation have assigned to the interstitial/lymphatic space an exceptional role in explaining enzyme activity changes in plasma. It was further shown that the plasma enzyme response to spontaneous running exercise in conscious dogs is quantitatively similar to the plasma 
Tab. 1. Enzyme activities in ly mph and plasma $(U / 1 ; \bar{x} \pm S E M)$ and lymph-plasma activity ratio $(\bar{x} \pm S E M)$ in order of dimishing lymph-plasma activity ratio.

\begin{tabular}{|c|c|c|c|c|}
\hline & Lymph & Plasma & & Ratio \\
\hline $\begin{array}{l}\text { Creatine kinasc } \\
\text { Malate dehydrogenase } \\
\text { Lactate dchydrogenase } \\
\text { Alkaline phosphatase } \\
\text { Aspartate aminotransferase } \\
\text { Aldolase } \\
\text { Adenylate kinase } \\
\text { Alanine aminotransferase } \\
\text { Leucine arylamidase } \\
\text { Choline esterase }\end{array}$ & $\begin{array}{r}110 \pm 13.8 \\
197 \pm 14.4 \\
98.1 \pm 7.7 \\
85.5 \pm 9.9 \\
19.4 \pm 1.7 \\
15.3 \pm 1.2 \\
28.8 \pm 3.6 \\
15.1 \pm 1.3 \\
6.3 \pm 0.5 \\
408 \pm 32.0\end{array}$ & 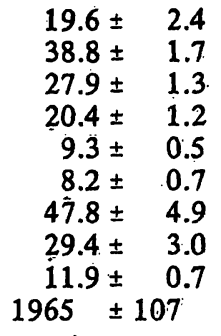 & $\cdot 1$ & $\begin{array}{l}6.5 \pm 11.0 \\
5.3 \pm 0.5 \\
4.0 \pm 0.4 \\
3.8 \pm 0.5 \\
2.4 \pm 0.3 \\
2.3 \pm 0.2 \\
0.6 \pm 0.1 \\
0.54 \pm 0.04 \\
0.53 \pm 0.05 \\
0.21 \pm 0.02\end{array}$ \\
\hline
\end{tabular}

The preliminary 15 min lymph samples of both experimental groups $(n=17)$ were taken for calculation together with the respective plasma samples prior to lymph sampling.

Tab. 2. Enzyme activities (U/g wet weight) of $M$. sartorius and M. gastrocnemius $(x \pm S E M, n=10)$.

\begin{tabular}{|c|c|c|c|c|c|c|}
\hline \multirow[b]{2}{*}{ Creatine kinase } & \multicolumn{2}{|c|}{ M. sartorius } & \multicolumn{4}{|c|}{ M. gastrocnemius } \\
\hline & 4148 & \pm 128 & 3720 & & 12 & $*$ \\
\hline $\begin{array}{l}\text { Malate } \\
\text { dehydrogenase }\end{array}$ & 781 & \pm 35.9 & 681 & \pm & 42.4 & $*$ \\
\hline $\begin{array}{l}\text { Lactate } \\
\text { dehydrogenase }\end{array}$ & 276 & \pm 17.8 & 548 & \pm & 27.5 & $* * *$ \\
\hline Adenylate kinase & 404 & \pm 34.6 & 391 & \pm & 28.4 & \\
\hline $\begin{array}{l}\text { Aspartate } \\
\text { aminotransferase }\end{array}$ & 130 & \pm 4.7 & 150 & \pm & 10.9 & \\
\hline Aldolase & 58.3 & \pm 3.1 & 99.1 & \pm & $11.6 *$ & $* * *$ \\
\hline $\begin{array}{l}\text { Alkaline } \\
\text { phosphatase }\end{array}$ & 0.63 & \pm 0.05 & 0.63 & & 0.07 & \\
\hline $\begin{array}{l}\text { Alanine } \\
\text { aminotransferase }\end{array}$ & 7.5 & \pm 0.18 & 6.29 & & 0.75 & \\
\hline Leucine arylamidase & 0.10 & \pm 0.01 & 0.10 & & 0.01 & \\
\hline Choline esterase & 0.35 & \pm 0.03 & 0.32 & & 0.03 & \\
\hline
\end{tabular}

Probabilities of significance between the muscles:

$* 2 \mathrm{p}<0.05$

$* * * 2 p<0.001$

enzyme response evoked by passive movement of the hind limb in anaesthetised dogs $(10,33,34,35,36)$.

Hind limb movement with sampling of propulsing lymph from hypoxic muscle may provide us then with a model for examining the mechanism of the exercise induced increases in plasma enzyme activity. The main intention of this study was to find an answer to the following questions:

1. Does a transient hypoxia of skeletal muscle induce a release of cellular enzymes and affect enzyme activity in plasma?

2 . If cell enzymes are released, do they reach the blood via lymph or by direct interstitial-venous entry?

As to the first question our results prove that enzyme activities especially those of the "muscle specific" type, like creatine kinase, lactate dehydrogenase, malate dehydrogenase and adenylate kinase show an increase in plasma in group 1 to 4 , which had been subject to passive motion; this was independent of hypoxia, which was only applied in group 1 . In the resting or immobilized leg muscle lymph flow is negligible as confirmed by others $(37,38)$. Truncus lumbalis lymph, which at least drains the total hind limb, contains enzyme activities, which compared to plasma are several times higher for the "muscle specific" type (tab. 1). During periods of physical activity or passive motion these activities reach the blood via ductus thoracicus in considerable amount. Recent investigations on changes in the flow of ductus thoracicus lymph, evoked by passive motion of the hind limb in anaesthetised dogs, have shown that these changes in fact can traced back nearly exclusively to lymph propulsion from the passively moved muscle by action of the tissue pump $(10,15)$. These observations then simply point to the importance of alterations of lymph flow from muscle for the adjustment of the level of cellular enzymes of muscular origin in plasma. Therefore enzyme activities in plasma in dogs of group 5, whose leg "rested" the entire period, remain unchanged, because enzyme-containing muscle lymph does not reạch the circulating blood.

Recently it was argued that the late onset $(8 \mathrm{~h})$ of enzyme activity rise in plasma after interruption of blood supply to resting leg is caused simply by hypoxic conditions (39). We cannot confirm these conclusions, because the enzyme pattern from the particular dogs in groups 5 and 6 was identical independent of hypoxia. It is suggested, that during long term anaesthesia the effects of shock allow inflow of enzymes from various tissues, but mainly from the viscera (25).

The results from the controls show that the influence of long lasting anaesthesia and surgery can be excluded as possible factors contributing to changes in plasma enzyme activity.

Comparison of enzyme patterns in lymph and plasma in groups 1 and 2 suggests that enzymes are released in the hypoxic group; both activities and transport of enzymes differ significantly in these two groups, especially for creatine kinase. This may partly be explained by condi- 
tions in the interstitial matrix, as the distribution space for enzymes. Proteins in the extracellular space for example normally are distributed in only a fraction of total matrix volume, simply because the matrix subunit density is extremely high in certain parts of the meshwork and consequently the albumin molecule cannot "fit" into these excluding domains. As the gel dehydrates, matrix density rises, the number of excluding domains rises, and the fractional distribution volume for albumin decreases (40). The protein exclusion on matrix dehydration counteracts the effects of decreasing lymph flow as occurred during our experiments, so that, in an extreme case, an increasing activity transport results for creatine kinase. Further support to this exclusion effect on enzymes is given by the fact that the continuously released cell enzymes, even under physiological conditions, are released into this compartment of the interstitial space, which is excluded from rapid exchange. These effects may explain the increasing enzyme activities in lymph despite decreasing lymph flow. These facts concerning the interstitial space are the common and main underlying mechanism for increasing enzyme activities in lymph independent of hypoxia. The partly higher lymphatic enzyme activities of the "muscle specific" type in the hypoxic group may in addition be explained by a limited swelling of muscle fibers by inflow of water from the interstitial space into the cells due to hypoxia, i.e. a supplementary amplified concentration effect as indicated by lower lymph flow in group 1.

Although an acute enzyme release from cells due to hypoxia cannot definitely be excluded it is suggested to be of secondary importance for the increasing enzyme activities in lymph.

From reports in the literature on energy rich substrates and glycogen in muscle after tourniquet application of up to $2 \mathrm{~h}$ duration $(41-44)$, it is suggested that the muscle cell is sufficiently protected against "blebbing" as the underlying mechanism for enzyme release of an energetically imbalanced cell $(45,46)$.

The conclusion on the first question is that inactive muscle cells are much less affected by a cut-off of external energy supply than had been expected. This statement definitely does not imply that active muscle also is resistant to hypoxia. It calls into question, however, the assumption which is often made that even a short-lasting relative hypoxia, as during strenuous exer.cise, can be the cause for an enzyme release from muscle. During passive motion or physical exertion an increase in lymph flow and thereby an increasing transport of enzymes from the interstitial to the intravascular compartment occurs, which especially for enzymes of the "muscle specific type" leads to considerable elevations in plasma in the initial phase. Clinical considerations, based on changes in enzyme activities in plasma alone would overestimate the actual release.
Some of the above conclusions, however, are based on the assumption that the predominant pathway for enzymes from muscle interstitium to blood is via the lymphatic system. Whereas an exclusively lymphatic pathway for macromolecules from interstitium to blood is unchallenged $(18-20,37)$, this pathway is called in question for enzymes by Bolter \& Critz (26, $27)$, and Szabó et al. $(23,24,25)$. This is somewhat surprising, all the more since the extremely low capillary permeability in skeletal muscle due to continuous capillaries has been considered $(16,47)$. The experimental design of the above mentioned groups, however, who provoked active motion of muscle by electrical stimulation, seems to be far beyond any physiological condition, in particular because of the high frequency (8$10 \mathrm{~s}^{-1}$ ) and amplitude (50-70 V) of stimula they used $(23,27)$. After $3.5 \mathrm{~h}$ of hypoxia to hind limb Szabó et al. (24) also found a significant arterio-venous difference in enzyme activity from which a direct interstitial-venous entry is concluded. Considering the massive metabolic and circulatory changes after long-term tourniquet ischaemia (44), it is highly probable, that a direct venous entry occurs. We, however, failed to find any significant differences between central venous blood and local venous blood: Recently we showed (10) that quantitative withdrawal of lymph from ductus thoracicus (which collects the lymph from nearly the whole body) after $1 \mathrm{~h}$ of hypoxia to one leg, revealed a tendency for plasma enzyme activities to decrease, rather than increase, a finding, which contradicts a direct entry of enzyme. In this study, however, enzyme activites in plasma of group 1 and 2 increased, despite lymph collection. The technique of lymph collection from truncus lumbalis, however, was not quantitative, and some lymph escaped the drainage through several cross anastomoses with the other side, and reached the intravascular compartment via ductus thoracicus.

Lymph-plasma quotients are useful in estimating origin and fate of a particular molecule in lymph and plasma. Lymph-plasma ratios in excess of unity indicate that the molecule derives primarily from the interstitial space. We recently introduced choline esterase as a more reliable marker than plasma proteins (21). Choline esterase is exclusively synthesised in liver. It has a molecular weight of 350000 and so defines the upper limit of the size of molecules we measured and which may get into the lymph only by a limited escape in the capillary area. Our results in table 1 prove that the cell enzymes we measured have significantly higher lymph-plasma quotients than that of choline esterase. So we can conclude that not only the group of enzymes with higher lymph-plasma quotient than 1 are of interstitial origin (e.g. creatine kinase, malate dehydrogenase, lactate dehydrogenase, adenylate kinase, aspartate aminotransferase and aldolase), but also those enzymes, which have a quotient exceeding that of choline esterase, like alkaline phosphatase, alanine aminotransferase and 
leucine arylamidase. We conclude therefrom that the cellular enzymes we found in lymph are primarily released from muscle into the interstitial space and reach the intravasal space preferably via the lymphatic system.

\section{References}

1. Houston, M., Green, H., Thomson, J. \& Reid, P. (1978) Eur. J. Appl. Physiol. 39, 145-154.

2. Berg, A. \& Haralambie, G. (1978) Eur. J. Appl. Physiol. 39, 191-201.

3. Fojt, E., Ekelund, L. G. \& Hultman, E. (1976) Pfluegers Arch. 316, 287-296.

4. Siest, G. \& Galteau, M. M. (1974) Enżyme 17, 179-195.

5. Friedel, R., Mattenheimer, H., Trautschold, I. \& Forster, G. (1976) this J. 14, 109-117.

6. Berg, A. \& Keul, J. (1977) Eur. J. Appl. Physiol. 36, 267273.

7. Haralambie, G. \& Berg, A. (1976) Clin. Chim. Acta 69, 433439.

8. Fowler, W. M., Gardner, G. W., Kazerunian, H. H. \& Lauvstad, W. A. (1968) Arch. Phys. Med. Rehabil. 49, 554-565.

9. Shapiro, V., Nagazanik, A., Sohar, E. \& Reich, C. B. (1973) Can. J. Physiol. Pharmacol. 51, 271-276.

10. Lindena, J., Küpper, W., Friedel, R. \& Trautschold, I. (1979) Enzyme 24, 120-131.

11. Szabó, G. (1978) Lymphology 11, 147-155

12. Werner, B. (1966) Acta Chir. Scand. 132, 63-76.

13. Kolc, J., Mrhóva, O. \& Málek, P. (1979) in Lymphology. Proc. of the VIth Intern. Congress (Málek, P., Bartos, V. \& Witte, M. H., eds.) Georg Thieme Publishers, Stuttgart, pp. 225-226.

14. Schad, H. \& Brechtelsbauer, H. (1977) Pfluegers Arch. 367, 235-240.

15. Schad, H. \& Brechtelsbauer, H. (1977) Pfluegers Arch. 371, $25-31$.

16. Renkin, E. M. (1968) in Lymph and the lymphatic system (Mayerson, H. S., ed.) Thomas Publishers, Springfield, pp. 76-88.

17. Taylor, A. E., Gibson, W. H., Granger, H. J. \& Guyton, A. C. (1973) Lymphology 6, 192-208.

18. Lassen, N. A., Parving, H. H. \& Rossing, N. (1974) Microvasc. Res. $7, \mathrm{i}-\mathrm{iv}$.

19. Noer, I. \& Lassen, N. A. (1978) Lymphology 11, 133-137.

20. Perl, W. (1975) Microvasc. Res. 10, 83-94.

21. Lindena, J., Küpper, W. \& Trautschold, I. (1981) Enzyme in press.

22. Friedel, R., Bode, R., Trautschold, I. \& Mattenheimer, H. (1976) this J. 14, 119-128.

23. Szabó, G., Anda, E. \& Vándor, E. (1972) Lymphology 5 , $111-114$.

24. Szabó, G., Anda, E. \& Vándor, E. (1972) Experientia 28, $1429-1430$.

\section{Acknowledgment}

This work was supported by a grant from the Deutsche Forschungsgemeinschaft.
25. Szabó, G., Vándor, E. \& Anda, E. (1973) Res. Exp. Meed. $161,39-48$.

26. Bolter, C. P. \& Critz̄, J. B. (1976) Enzyme 21, 30-38.

27. Bolter, C. P. \& Critz, J. B. (197.6) Arch. Int. Physiol. Biochim. 84, 115-128.

28. Nickel, R., Schummer, A. \& Seiferle, E. (1976) Lehrọuch der Anatomie der Haustiere, Bd. 3. Kieislaufsystem, Haut und Hautorgane, p. 361, Verlag Paul Parey, Bẹrlin.

29. Empfehlungen der Deutschen Gesellschaft für Klinische Chemie (1972) this J. 10, 182-192.

30. Chemnitz, G., Schmidt, E., Koller, P. V. \& Bush, E. W. (1979) Dtsch. Med. Wochenschri. 104, 257-260.

31. Winkel, P., Stadland, B. E. \& Bokelund, H. (1974) Clin. Chem. 20, 15.20-1527.

32. Sachs, L. (1973) Angewandte Statistik, Planung und Auswertung, Methoden und Modelle, 4. Auflage, Springer Verlag, Berlin.

33. Loegering, D. C. \& Critz, J. B. (1971) Am. J. Physiọ. 220, $100-104$.

34. Sanders, T. M. \& Bloor, C. M. (1975) Proc. Soc. Ex̄p. Biōl. Med. 148, 823-828.

35. Wagner, J. A. \& Critz, J. B. (1968) Proc. Soc. Exp. Biol. Med. $128,716-720$.

36. Bolter, C. P. \& Critz, J. B. (1974) Proc. Soc. Exp. Biol. Med. $145,1359-1362$.

37. Jacobsson, S. \& Kjellmer, J. (1964) Acta Physiol. Scand. 60 , 278-285.

38. Szábo, G., Magyar, Z. \& Posch, E. (1979) in Lymphology, Proc. of the VIth Internat. Congress (Malek, P., Bartos, V., Weissleder, H. \& Witte, M. H., eds.) Georg Thieme Publishers, Stuttgart, pp. 80-82.

39. Bertram, E., Schultz-Hector, S., Eberle, R., Spillner, G. \& Trendelenburg, $C$. (1977) VASA 8, 98-101.

40. Granger, H. J. (1979) Microvasc. Res. 18, 209-216.

41. Haljamäe, H. \& Enger, E. (1975) Ann. Surg. 182, 9-14.

42. Stock, W. \& Isselhard, W. (1972) Vasc. Surg. 6, 255-262.

43. Larsson, J. \& Hultmann, E. (1979) Scand. J. Clin. Lab. Invest. 39, 257-264.

44. Harris, R. C., Hultman, E., Kaijser, L. \& Nordesjö, L. O. (1975) Scand. J. Clin. Lab. Invest. 35, 87-95.

45. Diederichs, F., Mühlhaus, K., Trautschold, I. \& Friedel, R. (1979) Enzyme 24, 404-415.

46. Friedel, R., Diederichs, F. \& Lindena, J. (1979) in Advances in clinical enzymology (Schmidt, E., Schmidt, F. W., Trautschold, I. \& Friedel, R. eds.) Karger, Basel, pp. 70-105.

47. Courtice, F. C. (1971) Lymphology 1, 9-17.

Dr. med. vet. Joạchim Lindena Medizinische Hochschule Hañnover Zentrum Biochemie Abteilung für Klinische Biochemie Karl-Wiechert-Allee 9 D-3000 Hannover 61 